\title{
Researching Local and National Pluralism: Britain's New Religious LandSCAPE ${ }^{1}$ Kim KNotT
}

This paper presents an analysis of the spatial representation of some of Britain's newer religions at both local and national level. Their changing presence in the geographical, social, political and religious landscape is considered, as is the way in which they have engaged with the dominant order and local micro-cultures. I begin by introducing the spatial methodology to be used in the paper through its application to the case of a domestic murder in London in $2003 .{ }^{2}$

\section{A recent case and some methodological comments}

On 30 September 2003 at the Old Bailey in London a Kurdish man was imprisoned for life for murdering his I6-year old daughter in what is commonly referred to in the media as an shonour killing : To quote from a headline in The Guardian newspaper of 30 September,

»Kurd who slit daughter's throat in shonour killing is jailed for life. Muslim father of girl, $\mathrm{I} 6$, who had relationship outside her religion, subjected her to months of beatings before stabbing her repeatedly.«(Dodd 2003)

I This was first given as a keynote paper at the Internationale Jahrestagung der Schweizerischen Gesellschaft für Religionswissenschaft: Religiöser Pluralismus im Lokalen Raum, 24-25 October 2003 in Lucerne. An earlier version of parts of the paper appeared in Berichte zur deutschen Landeskunde 78 , 2 (Knott 2004a).

2 This case was selected because it was in the news when I gave the original paper in October 2003. I wanted to show that a spatial analysis could be used to illuminate the place of religion in any given case so I chose a current one in which social and religious diversity was debated.

3 Elizabeth Poole, in a book on media representations of Islam, reminds us that »we cannot [...] divorce sevents < from their reporting, for this is how they acquire their meaning " (2002: I5). That is very clear in the case of >honour killing . Media and other public agencies have created the notion of shonour killing ( perhaps borrowing it originally from the discipline of anthropology) to describe a community-based murder motivated by strong feelings associated with honour and shame. As Poole writes, there can be no »transparent process of re-presenting an objective reality« (ibid.: 23). This 
Some important religio-political issues were raised by this event and its reporting. These included whether such killings are religiously or tribally motivated, and whether shonour $<$ is a religious notion at all. Was it helpful to distinguish shonour killings < from other types of domestic abuse of women? Did identifying such crimes as >cultural< or >religious discourage the police and other agencies from becoming involved in such incidents on the assumption that they were community and not public matters? ${ }^{4}$

What we saw in the reporting of this case were some of the problems that arise from the attempt to separate religion from other social and political domains. First, they are difficult if not impossible to differentiate; second, the consequences of separating them are sometimes unhelpful and damaging. The more clarity that can be brought to bear on the relationship between religion and other aspects of culture and society the better it will be for both scholars and the wider public who have to make sense of the way religions function in everyday life. A spatial approach that allows us to look closely at the location of religion in a variety of >spaces < - whether these are places, bodies, things, events or organisations - can help us to discern how religion relates to other domains, how it operates in the ostensibly secular world, and the way in which it is interwoven with the struggle for power (Knott 2005). It is just such an approach that I have employed here.

An shonour killing < is a power struggle in which one party takes the law into shis crime, the reporting of the events, and the intellectual evaluation of them are also struggles involving power, whether embodied in institutions, legal representation, news headlines and editorials, or ideological debates between interested commentators. Like all struggles, they are played out spatially - whether in physical, social or ideological space -

holds true for the many other acts of representation alluded to in this paper, including the one implied within its title: Whilst we evidently have both ethnic and religious diversity or plurality in Britain, even to classify Britain's minority populations as >black or black British<, >Asian or Asian British<, or, alternatively, as >Christian $<$, >Buddhist $<$, >Hindu<, >Muslim $<, ~>$ Sikh $<$ is an act of representation which takes us from mere plurality into the territory of pluralism. Furthermore, in Britain there are now many pluralisms, that is, many different attempts to codify, describe, explain, and idealise social and cultural diversity.

4 These and other questions have been raised in recent years by critical voices in the British news media (Allison 2003; Asthana/Mistry 2003; Dodd 2003; Gupta 2003; Alam 2004). 
and are thus amenable to a spatial analysis. ${ }^{5}$ In the tragic case of Heshu Yones, the young victim, the first site of struggle was her own home, a place that was meant to be safe and secure. ${ }^{6}$ Other important sites were the court of law, the Old Bailey, the public area outside it where legal representatives made statements to the hungry media, the news media themselves and the spaces they filled with stories and comments about the case, and the metaphorical spaces of cultural interpretation, whether anti-communalist feminist, patriarchal Kurdistani, Islamist, or western secularist (and there were competing renditions of each of these).

Were we - as scholars of religion - to choose to investigate the place of religion in such a case, we would find a focused analysis of these multiple spaces helpful for exploring the relationship between religion and other aspects of the case (whether tribal, criminal, legal, gender-oriented or rights-based). We would learn more about the way in which the media represent religion and relate it to other concepts, domains, and human activities. By looking at the various spaces that contribute to this case we would also see how different parties use such spaces to present their own perspectives on these tragic events - to defend this killing as one motivated by honour (and thus specific to certain ethnic communities), to describe it as a domestic murder driven by patriarchal ends, to represent it as an expression of the sacrality of moral and ethnic boundaries, to understand it as contravening the human right to life. Henri Lefebvre, whose ideas about space and its production and reproduction are at the centre of my approach to the location of religion, identifies the following dimensions of space: »[First] the physical - nature, the Cosmos; secondly, the mental, including logical and formal abstractions; and, thirdly, the social.« (Lefebvre I99I: II) He invites us to examine them together as a means of reuniting previously separated fields of enquiry. He also reminds us that, in space and its dimensions, values take shape and compete with one another, and power struggles are enacted (ibid.: 4I6-4I9).

In the remainder of this paper Lefebvre's ideas will not detain us, but the discussion will be premised upon them - that Britain's newer religions (those borne in by migrants and refugees) are struggling to make room for themselves in a predominantly secular space, and that

5 Following Henri Lefebvre's three dimensional view of space (I99I: II), and his view that all struggles are spatial and that spaces are fought for and contested (ibid.: 410-420).

6 See Tobler 2000 for a discussion about the home as both gendered sacred space and site of gender struggle. 
they are doing so on all fronts by asserting themselves physically, mentally or ideologically, and socially. A spatial analysis - in this case an examination of the effect of these religions upon the landscape - can assist us in understanding the changing nature of their presence and the way in which they have engaged with both the dominant order of government and public institutions and the everyday order of local political and social life.

In this analysis of Britain's new religious landscapes, I shall use the terms >space< and >landscape< to refer to practices, artefacts, arenas and institutions with a material - as well as mental and social - dimension. ${ }^{7}$ By landscape I shall mean a physical space formed by both nature and culture, socially inhabited, and prone to representation such that it is often known only by its representations. ${ }^{8}$ But no landscape is uncomplicated. Both de Certeau (I984: 20I-202) and Park (I994: I98), have seen landscape as a palimpsest, a manuscript on which two or more successive texts have been written, each one being erased to make room for the next. As Lefebvre (I99I: I42-I43) suggested, interpreting the repeatedly over-written landscape, not least of all its most recent text, requires geographical and historical knowledge, but also a sense of the social, cultural and political processes which produce it.

My main concern, however, will not be a consideration of the meaning or nature of the British landscape as such, but a spatial examination of some key aspects of the representation of new religions in Britain since 1970. In the next section, I shall briefly review the rise of religious diversity as it has been discussed by those with an interest in social and cultural geography. ${ }^{9}$ Two sections then follow, focusing on first the local and then the national scale. In both, several interrelated themes will be discussed: the place of worship, inter-religious engage-

7 Lefebvre speaks of »mental space« (I99I: II), but includes within that an acknowledgement of the role of power and ideology. Although the inclusion of the material dimension may sound too obvious to be worth mentioning, Jackson recently thought it necessary to call for a »re-materialisation « of social and cultural geography (2000).

8 See Muir I999: 2-12 for a discussion of the interpretation of landscape. See also Eade 2000 on the landscape of London and its representations.

9 Non-Christian religions were being established in Britain before 1970 (for historical accounts, see Thomas I988; Badham I989; Parsons I993; Knott I997; Weller 200I). I have chosen that date in particular because it was in I97I that the first book was published that drew attention to a spatial consideration of these religions (as well as Christian and quasi-Christian churches and movements). 
ment, and religion in the public domain. Finally, I shall draw some conclusions about the changing religious landscape in Britain before returning briefly to the value of a spatial approach for researching religion at local and national levels.

\section{Britain's new religious landscape since 1970}

John Gay published his geography of religion in England in I97I. In pursuit of his quest »to examine the part played by the religious motive in man's transformation of the landscape (Isaac in: Gay I97I: I8) and after considering the major Christian denominations and the smaller Christian groups present in Britain, he then moved on to discuss eastern religions and Judaism. Despite his interest in the growing religious diversity of England, he seemed unable to imagine a religious future beyond secularisation and assimilation. Of Hindus, he concluded that they »leave their religion behind in India and fail to give their philosophy of life any organizational expression in this country « (ibid.: 20I). ${ }^{\mathrm{I}}$ Of Sikhs and Muslims, he predicted that the youth will »quickly fall in with the norms and values of British society« (ibid.). After recognising the role of England's Jews in developing close-knit communities, he wrote that »slowly but inevitably [they] are being absorbed into the prevailing national culture [...]. Eventually English Judaism is likely to become the concern of the historical geographer« (ibid.: 220).

We need only look at the publications of those scholars with a concern for geography who have written about religion in Britain in the last decade to see that Gay's predictions were wrong. They were the function of a secular consciousness that saw religion as under threat and ethnic identity as prone to death by assimilation. Hindus in fact have developed many institutions in Britain since the I970s (Knott 2000a; Naylor/Ryan, in press). Muslims have defied the norms and values of British society and the process of assimilation by establishing purpose-built mosques (Eade 1996; Naylor/Ryan, 2002), by pressing for their own schools (Dwyer 1993), and by asserting their own styles of dress and performance in the public space (Dwyer I999a and I999b; McLoughlin 1998; Werbner 1996). Some Jews, of course, have stressed ethnic rather than religious identity, but others have fought strongly to assert their difference through separate communities of faith (Valins 2003). Recent research on these groups has shown that religion plays an important role in determining patterns of settlement (Phillips n.d.; 
Valins 2003), in identity formation, often superseding the determinants of race and ethnicity, (Peach 2002; Chivallon 200I), and in the legislation and practice of urban planning (Gale/Naylor 2002). Furthermore, counter to Gay's pessimism, the size of all these groups has increased - except the Jews for whom emigration to Israel and some out-marriage have brought about a gradual decline in numbers. This is shown in a comparison of figures for England and Wales for the lateI970s and 200I. ${ }^{\text {II }}$

\begin{tabular}{|l|l|l|l|l|}
\hline & Muslims & Hindus & Sikhs & Jews \\
\hline I977 & $353,6 \mathrm{IO}^{\text {I2 }}$ & $306,94 \mathrm{I}$ & 304,950 & $(300,000)$ \\
\hline $200 \mathrm{I}$ & $\mathrm{I}^{2} 59 \mathrm{I}, \mathrm{I} 26$ & $558,8 \mathrm{IO}$ & $336, \mathrm{I} 49$ & 266,740 \\
\hline
\end{tabular}

A key feature of religious change in Britain in the last 30 years, then, has been the growth of religious diversity. ${ }^{13}$ This has been accompanied by a parallel development, the rise of identity politics. Commentators have explored the relationship between the two processes in terms of >community $<$, >culture $<$, new forms of identity, and the redefinition of established loyalties and networks. ${ }^{\text {I4 }}$

II Figures for 1977 were based on information from the I97I population census, updated for 1977, and the results of the 1976 labour force survey (Knott/Toon 1982). Figures for 200I are taken from population census data for England and Wales (www.statistics.gov.uk/census2001/). It is estimated that the Jewish population fell in this thirty year period from about 300,000 to 266,740 .

I2 The I977 figure for Muslims included only those with ethnic origins in the Indian sub-continent (Knott/Toon I982). The equivalent figure for 200 I exceeds one million, with more than $73 \%$ of Muslims professing an Asian or British Asian identity.

I3 See Thomas I988; Badham I989; Parsons I993; Knott I997; Weller 200I.

I4 On >community<, see Baumann I996, Dwyer I999a, Knott 2004b; on >culture<, Baumann I996, Caglar I997, Parekh 2000a, Nye 200I; on new forms of identity, Nesbitt I998, McLoughlin I998, Dwyer I999b, Chivallon 200I; and on established loyalties and networks, Vertovec/Cohen I999 and Vertovec (2004). This is just a selection of the many publications on these topics. 


\section{Religious diversity and pluralism: the local scale}

Investigating this religious diversity at local level (the city of Leeds) and regional level (the region of Yorkshire and the Humber) has been the purpose of the Community Religions Project (CRP) at the University of Leeds since $1976 .{ }^{15}$ Reflecting on the value and interest of taking the religions of the locality as a scholarly starting point, the first director of the CRP, Michael Pye, wrote that:

»By now the City of Leeds itself contains population elements from south and east of the Hindu Kush. In addition the hymns of Martin Luther are sung in German, the Catholic mass is celebrated by Poles, and Greek Orthodox perform their exits and entrances in the Church of the Three Hierarchs directly beside the main West Indian and Sikh communities of Chapeltown. Moreover, Yorkshiremen are interesting too, and so is the Church of England in its mysterious empirical forms.«(Pye I977: I)

This became the initial motivation and focus for the research that was to follow: studies, for example, of Hindus, Sikhs and Greek Orthodox as well as popular religion - in Leeds, and of Bengali and Pakistani Muslims and Sathya Sai Baba devotees in Bradford. ${ }^{\mathrm{I}}$ The attention to local detail was pursued further from I994 when teams of students first began to map the place of religion in the city of Leeds and its engagement with other social, educational, political and economic concerns. ${ }^{\text {I7 }}$ During the same period, other studies were undertaken, often involving partnerships with local religious and secular agencies.

I5 I have discussed the work of the Community Religions Project in various articles, see Knott I984, I988, I998, 2000b, 2004b.

I6 This local focus was soon widened to include similar community-based studies situated in other localities, such as Polish Catholics in London, Buddhists in Bath, young Sikhs in Coventry, and young Pakistani Muslims in Oslo. For a full list of the publications of the Community Religions Project, see www.leeds.ac.uk/trs/

I7 >The Religious Mapping of Leeds< is a team work project run for undergraduate and masters students in the Department of Theology and Religious Studies at the University of Leeds. The areas mapped to date include the neighbourhoods of Beeston (I994), Moortown (I996), the city centre (1997), Armley (2000), the University of Leeds (2002), and South Headingley/Burley (2004). Reports are available for most of these mappings, see www.leeds.ac.uk/trs/ For a discussion of the pedagogical value of religious mapping, see Knott 1998. 
In I994, a collection of essays was published on Religion in Leeds (Mason 1994) to mark the city's centenary. From I996-98, the Department of Theology and Religious Studies joined forces with Leeds Church Institute to conduct a local study of inter-religious social action, which concluded with an international conference on the subject of religion and locality (Knott et al, in press) and a final report entitled Faith in the Future: People of Faith, Social Action, and the City of Leeds (Burlet/Reid I998). Since 200I, the CRP has worked with the Churches Regional Commission, the Yorkshire and Humber Assembly, Leeds Faith Communities Liaison Forum, and the British Government's Home Office to study religious literacy in Yorkshire and the Humber, the feasibility of a regional faiths forum, and the effectiveness of consultative processes between government and local faith communities.

This work demonstrates the need, in Britain at least, for research on the interface between the priorities and experiences of religious communities and public bodies, particularly national, regional and local government and those agencies established to enact their policies. It also reveals the demand of secular institutions and the religiously illiterate for information about religions, their local social expressions, their beliefs, practices and values, and the way in which these affect the democratic participation, social inclusion, and public order of minority populations. ${ }^{18}$ When the CRP was first set up, the ideologies of government, law and the media in Britain were firmly secularist in orientation. Although this is still largely the case, there is now much greater recognition that secularisation has only partially occurred. Religion has not disappeared or died out, but has been revitalised by the presence of those religions carried to Britain by migrants and refugees. The current Prime Minister, Tony Blair (a Christian socialist), has called for >faith communities < to be involved in partnership with local government and statutory agencies in the process of urban regeneration; the Deputy Prime Minister, John Prescott, has called for such communities to be consulted on relevant matters of public policy. ${ }^{\text {I9 }}$ For successful im-

I8 The need for >religious literacy< in the region was the subject of Knott/ Randolph-Horn 2002.

I9 See Blair 200I, Office of the Deputy Prime Minister, Neighbourhood Renewal Unit (Inner City Religious Council), http://www.neighbourhood.gov. $u k / f a i t h \_c o m m u n i t i e s . a s p$, and the Faith Communities Unit of the Home Office, http://www.homeoffice.gov.uk/docs3/workingtog_faitho40329.pdf. The term >faith communities < is commonly used in British public discourse by secular and religious representatives alike to refer to the social organisation 
plementation of such policies, things have to change at local level. And it is here that a research project like the CRP can play a part, in mapping the religious terrain, communicating information about religions to those who need to know, and in undertaking research which helps to facilitate this two-way process between local religious communities and the wider public domain and its agents. ${ }^{20}$

Having given some attention to religion in the local public domain, I shall now turn to spaces of worship and encounters between religious groups. I begin by looking back to April I999.

Figure 1: The 1999 inaugurated gurdwara on Chapeltown Road, Leeds, on Vaisakhi

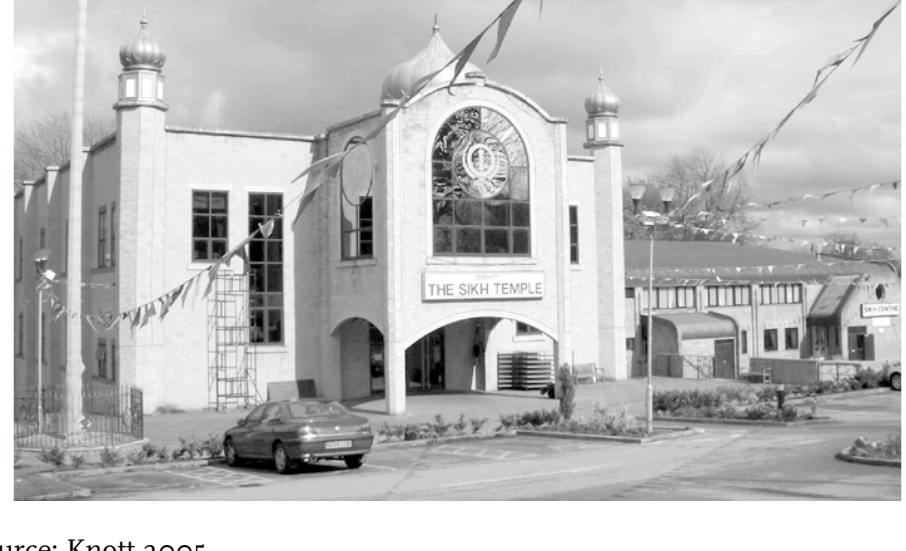

Source: Knott 2005

It is Vaisakhi, the tercentenary of the Sikh khalsa, 300 years on from that momentous occasion when Guru Gobind Singh is said to have demanded the self-sacrifice of five followers only to transform them through amrit or initiation - into Sikhs. In Leeds a splendid new gurdwara is opened (to add to the five others already flourishing in the city). It has been built at much cost and local voluntary effort (sewa) in a

of religious people into communities of interest (often determined by ethnic and linguistic as well as sectarian factors). I shall continue to use $>$ faith communities < in this sense.

20 There are important issues here of research ethics, the values and standpoint of researchers, the role of >caretaker or critic $<$, and issues of objectivity, involvement in public issues and debate, even advocacy. For discussion of these, see McCutcheon I997, Cady et al. 1998, Knott 200ob. 
prominent position on a main arterial route running north out of the city centre, on Chapeltown Road. The new gurdwara is huge, one of the largest in Britain, with parking available for hundreds of cars, and space for large social as well as religious occasions. Its trustees and patrons see it as a flag-ship among Leeds gurdwaras, and a local civic landmark. ${ }^{2 \mathrm{I}}$

Let us look more closely though. What does a spatial analysis reveal? First, this gurdwara is on the city's major migratory route, from the inner city to the affluent suburbs. ${ }^{22}$ Through this geographical corridor have passed those aspiring Yorkshire citizens escaping the filth of nineteenth century urban Leeds and heading for greener pastures, Jews in the first half of the twentieth century (now residing out as far as the spa town of Harrogate), Eastern Europeans and South Asians - particularly Sikhs who are on the same upwardly-mobile social trajectory. The area in which the gurdwara is situated is now largely African Caribbean. But its history can still be discovered in the landscape. Within a radius of half a kilometre from the gurdwara can be seen nineteenth and twentieth century churches, a synagogue from the I930s (now the Northern College of Dance), and houses and other buildings converted for use by Polish Catholics, Ukrainians, Greek Orthodox, other Sikh groups, Muslims and Black Christians.

Secondly and more precisely, if we stand with our backs to the new gurdwara, we face its predecessor, evidently a building that was once a church, but one that from I96I to I999 housed the main gurdwara for Leeds Sikhs, the >Leeds Sikh temple< as it was always known. ${ }^{23}$ [Round to one side of it there is another building on the same site that has been used at times as a black Pentecostal church and a Hindu temple.] In these recycled sacred buildings different religious groups have found a temporary home, from the Congregationalist and Baptist Christians who first founded their >unity church< here in 1887 - a startlingly original venture for its time in what was then a garden suburb (Binfield I994: I04) - to the Punjabi Sikhs and Hindus of the I960s in what had

2I That places of worship have acquired this status in Leeds is demonstrated by their inclusion in a series of >Heritage Open Days < organised by Leeds Civic Trust and Leeds City Council.

22 See Phillips (n.d.) for recent research on South Asian settlement and mobility within Leeds.

23 Pictures of the new and old gurdwaras can be seen in http://www.hathisoft. com/sikhism/Gurdwaras/gurdindx.htm. 
by then become part of the inner city. ${ }^{24}$ Inside and outside the building the traces of both Christian and Sikh usage can still be seen. ${ }^{25}$

Figure 2: The former main gurdwara for Leeds Sikhs situated in a recycled church (copyright Community Religions Project, Leeds)

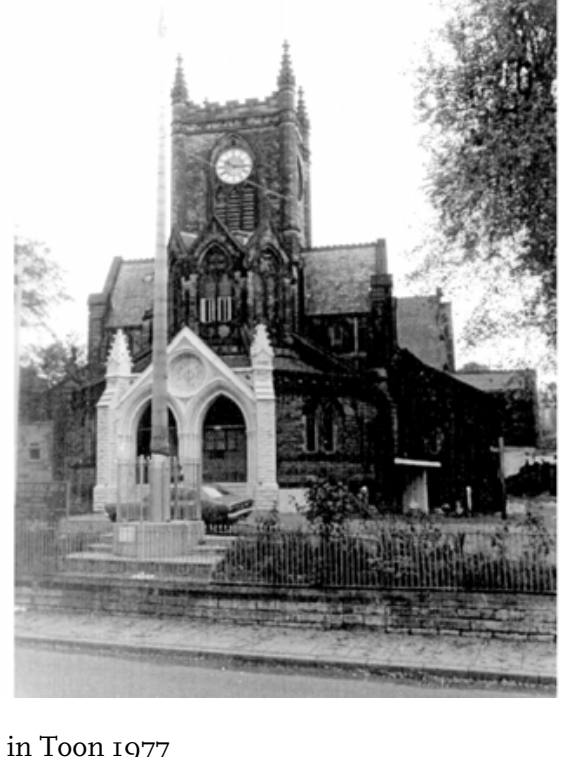

Source: Kellgren in Toon I977

In this spatial reflection, we see what is primarily a history of >replacement<, of one community moving in as another moves out, not entirely removing the traces of the first, but certainly taking up what was once its space. In other situations, however, the spatial arrangements whether temporary or permanent - reflect not replacement but the encounter between groups: in the case of the »Sikh Christmas dinners « in the I970s, for example, when local dignitaries from Christian churches and other religions were invited by the Sikhs to a nearby school to

24 In their early years in Leeds Punjabi Sikhs and Hindus worshipped together. Theological differences later drove them apart (Knott/Kalsi I994: I66-i67).

25 And the stories of both are told in different chapters of Mason's edited collection, Religion in Leeds (Binfield I994; Knott/Kalsi I994; see also Toon I977 and Kalsi 1992). 
celebrate the season of goodwill (Knott/Kalsi I994: I75). A contemporary example, which has led to the development of new shared community space, is the working relationship between Methodist Christians and Bangladeshi Muslims living in the neighbourhood of Beeston in South Leeds (Prideaux 2004). Another, which is principally a social and mental rather than physical space, is the Leeds Faith Communities Liaison Forum, a network linking representative faith bodies (such as Leeds Buddhist Council and Leeds Islamic Forum). ${ }^{26}$ This new opportunity for inter-religious encounter is not limited to dialogue on matters of belief and practice, but provides both a mechanism for faith groups to engage with local government on issues of public policy and a means by which they can bid - together - for funding to regenerate their neighbourhoods and communities. Public investment in religion in Leeds is now a multi-faith concerns. If a single religious group wishes to develop its own social or physical space, it must now do so from within its own resources. The rhetoric and ideology of multiculturalism are now issuing forth in practical multi-faith projects which will still further alter the Leeds landscape in years to come.

\section{Religious diversity and pluralism: the national scale}

As we have seen at the local level, the growth of religious diversity since the mid-twentieth century has changed the physical landscape of Britain, in both its urban and suburban settings. Furthermore, it has changed the way in which religions new to Britain are represented: As John Eade noted, mosques have become places »not only for prayer but for representation of the Muslim presence (Eade 1996: 227). ${ }^{27}$ And a similar process has occurred with temples and gurdwaras. Simon Naylor and James Ryan (in press), with reference to a major national study of Islamic, Hindu and Sikh places of worship, have confirmed the scale of the change, noting that, in 1964 , there were thirteen officially certified sites of worship rising to 6I4 certified mosques, Io9 Hindu temples or mandirs, and 193 Sikh gurdwaras by $1998 .^{28}$ In many cases,

26 Information about the Beeston project and Leeds Faith Communities Liaison Forum can be found in Knott/McLoughlin/Prideaux 2003.

27 Although the post-war period has seen the establishment of South Asian religious communities, there were in fact several mosques (I887, I884, I926) and a gurdwara (I9II) opened before that time.

28 See publications by James Ryan, Simon Naylor and Richard Gale arising 
and particularly in the period to I980, new religious communities recycled buildings used for other purposes, such as houses, schools, factories and churches. Although building exteriors were sometimes modified, and communities often announced their presence with billboards featuring the name of the group and other manifest symbols, such as the Islamic crescent and Hindu and Sikh flags, the outward appearance of these places of worship generally made little overt impact on the environment (though the exits and entrances of worshippers, particularly their use of local roads and parking facilities, sometimes attracted attention). Inside, however, these places of worship often contained material secrets that many of those critics who were fearful of »an alien invasion of local space « (ibid.: 23I) would have found profoundly challenging: Hindu icons or murti (including pictures of goddesses and divine animals alongside Jesus and the Buddha), the Islamic qibla, directing the prayerful attention of Muslims towards Mecca, and the central presence in the gurdwara of the Sikh holy book to which worshippers paid obeisance. However, to quote a well-known English phrase, »What the eye doesn't see, the heart doesn't grieve over«. Thus, it was not the spatial practices and material features occurring behind the closed doors of these outwardly familiar buildings that caused alarm, but the social and cultural challenges that arose from the construction of new buildings.

The responses of local people to purpose-built mosques, gurdwaras and mandirs often took the form of complaints about parking and traffic congestion (Gale/Naylor 2002: 392-394), but sometimes of more outspoken objections concerning the perceived threat to the appearance and ambience of the local area, whether through the islamicisation of »the garden suburb « of Northolt (Eade 1996: 228), or the »inappropriate erosion of the local community with the development of the Swaminarayan Hindu temple in Neasden (Naylor/Ryan, in press). ${ }^{29}$ In such cases, alien cultural traditions were thought by some local people to be transforming the English suburban landscape in an unwelcome way. Other local voices - often liberal, self-consciously anti-racist, and either secular or Christian - embraced more positively the transition and its social and ethical possibilities for »welcoming the stranger«,

from >Ethnicity and cultural landscapes $<$, a research project funded by the Leverhulme Trust, I998-200I at the University of Oxford (and directed by Ceri Peach).

29 Northolt and Neasden are both London suburbs. 
»living together in harmony«, and for providing »equality of opportunity.$^{30}$

Figure 3: Postcard of the Swaminarayan Hindu Temple, North London' (copyright Swaminarayan Hindu Temple, 1995)

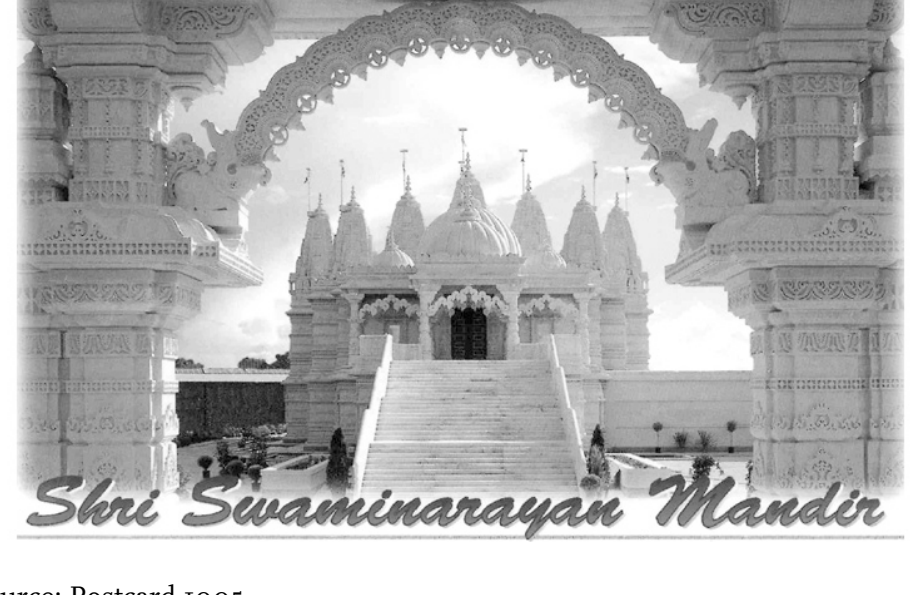

Source: Postcard I995

As Naylor and Ryan (2002, and in press) have suggested, colonialist impulses have often been behind the expression of opinions about the development of Islamic, Hindu and Sikh places of worship in Britain. This, together with a related nostalgia for >English-ness $<$, has often been interwoven in the minds of many with what it means to be >British.$^{3 \mathrm{I}}$ Unsympathetic discourses, whatever their source or motivation, have not been confined to public complaints and challenges, however. They have also been enshrined in local planning law and decision-making. These have, until recently, lacked any provision for religious freedom and have been conservative with regard both to changes in the use of buildings and to the construction of new places of worship, especially where these are thought to endanger what planners call

30 These are all phrases used in recent publications on the contribution of faith communities to local civic life in Britain.

3I The relationships between England and Britain, and between English and British identities have been much debated in recent years, with innovative inclusive and pluralistic notions of the latter beginning to emerge. See in particular Parekh $2000 \mathrm{~b}$ and other articles in the same issue of Political Quarterly, and Kumar 2003. 
samenity< or the intrinsic features of a given locality (Gale/Naylor 2002: 389).

Seen from a postcolonialist and anti-discriminatory perspective with regard to religion, the presence of new religious landmarks is a positive sign in the transition to new British identities, not only those of a hyphenated variety like British-Muslim and British-Hindu, but also those associated with »local multicultures « in which people initiate civic projects which serve both their own and wider local interests (Ash 2002). New places of worship and their associated community spaces may be used for diverse social action initiatives, such as multicultural gatherings, immigration advice centres and cross-community facilities for the young or the elderly. This negotiated process - in which a wide range of groups, individuals and agencies participate - is in some parts of Britain supported by increasingly imaginative and inclusive planning practices (Gale/Naylor 2002: 395-405). Furthermore, purpose-built places of worship may quickly become part of the local - and sometimes even national - heritage, attracting interested tourists as well as worshippers, and becoming significant sites in the landscape (Ridout 2000). Well known examples in England's capital include the Swaminarayan Hindu Temple in north London, referred to by Reader's Digest as »the eighth wonder of the world «, and Regent's Park Mosque.

Additionally, seen from the perspective of the faith communities who build and maintain these new mosques, gurdwaras and mandirs, they have the benefit of providing much needed local religious space, designed specifically for the purposes of ablutions, worship, education and social life. Simultaneously, they both sacralize a space (Chidester/ Linenthal 1995; Metcalf 1996) and make a statement about a faith community's place in and contribution to local life. Their spatial relationship to other places of worship - whether of the same religion or others - may well reveal issues of intra- or inter-community contestation and rivalry. Studies of particular localities, the places of worship within them, their interrelationship, outreach, and socio-economic embeddedness can be informative, as we saw earlier, for understanding the place of religion in local landscapes (Knott 2000b).

The development of new places of worship has not been the only way in which religious plurality in Britain has affected the landscape. Increasingly, since the coming to power of >New Labour < in I997, faith communities have found it useful to work separately and together to keep religion on the public agenda of social inclusion, and to maximise the opportunity to obtain funding and support. ${ }^{32}$ One national network 
has been central in this process. The Inter Faith Network for the UK was founded in 1987 with a membership of representative faith bodies, national inter-faith organisations, local inter-faith groups, and educational bodies with an interest in multi-faith issues. It has aimed »to advance public knowledge and mutual understanding of the teachings, traditions and practices of different faith communities in Britain [...] and to promote good relations between persons of different religious faiths « (Weller 200I: 80). ${ }^{33}$ Although it occupies office space in central London, it is characterised spatially by networked communications with its member bodies, and by regular annual meetings in different locations at which representatives from various religious organisations and inter-faith groups get together to discuss common interests such as education, media, young people, and service to the community. Its other key roles are in representing contemporary religious issues to government and other statutory bodies and in informing them about the contribution of faith communities to public life. Examples include the Network's contribution to events during the year of the Millennium, its work with the Local Government Association, and its role in research on religious discrimination funded by the Government's Home Office (Weller et al. 200I). ${ }^{34}$ Following the adoption in 2003 of equality legislation on religion and belief, it assisted by providing information for employers and trainers on religions in Britain, their beliefs and practices. It has been an effective player in keeping religion in the public eye<, in other words, in drawing attention to its place in the landscape.

ties in urban regeneration and regional development have increasingly encouraged close interreligious relationships and arrangements (arguably as a means of social control and community cohesion). See Burlet/Reid I998, and reports on these issues available on the following websites: www.inter faith.org.uk, www.lga.gov.uk (see publications on >faith communities<), www.rayh.gov.uk (see >The feasibility of a faith forum<).

33 For additional information on the Inter Faith Network for the UK, see www.interfaith.org.uk.

34 This research has contributed in part to legislative and policy change in the UK. In December 2003, in order to bring England and Wales in line with European Council directives, Employment Equality (Religion and Belief) Regulations 2003 was introduced. It offers legal protection to employees from various forms of discrimination in the workplace. Its introduction was followed in 2004 by consultation and planning for a single equality commission to include religion and belief along with race, gender and other human rights. 


\section{Britain's dynamic religious landscape through a spatial approach}

Even in an apparently secular era, religious people have left their marks on the British landscape. These distinguishing features are sometimes contested, as in the planning of new places of worship, the conduct of public festivals or processions, or the demand by religious bodies for civil rights. These features are often difficult to interpret. When one faith group recycles a building once used by another, how are we to understand the place of religion therein? The symbols and meaningful physical arrangements of the first are overlaid by the second, and may either be forgotten or reinterpreted. These are the »imbricated stata « referred to by Michel de Certeau (I984: 200), the »piling up of heterogeneous places « (ibid.: 20I) which overlap, poke through, and provide directions to separate historical landscapes. But, as we have seen, new religious spaces are not always physically embodied. Sometimes they emerge in public discourse, in negotiations between people of different religions, or in networks of mutual self-interest and opportunity. As we saw in the case of Leeds, though, these social and discursive spaces can lead quickly to adaptations in the physical landscape, whether temporary or permanent.

What we see suggests four possible areas of change in Britain's new religious landscape. The first concerns religious literacy, that is, people's general knowledge and awareness of religions, their beliefs and practices, communities of faith, needs and rights, and public contribution. With fewer people attending churches and nurtured in Christian values and teachings (and here we must concur with the secularisation thesis), there is a significant lack of religious literacy. However, the making of a religiously diverse landscape and the transformation of familiar everyday spaces (streets, parks, shops, homes) into temporary, and sometimes permanent sacred sites gives public acknowledgement to the place of religion, helps to make people aware of religious plurality, and opens up the possibility of their wider civic participation in religious cultures.

Secondly, from the perspective of committed practitioners themselves, such a religious presence denotes the sacralisation of urban spaces. A landscape which is commonly reported to be industrialised, commercialised, secular and material is re-imagined and reclaimed as >sacred<. In an article on a Sufi procession in Birmingham, Pnina Werbner (I996: I67) writes of Muslims »stamping the earth with the name of Allah«. Whether it is through the ritual performance of processions or festivals, the erection of new places of worship, or the reli- 
gious infection of public and private spaces, the march of sacralisation - as opposed to secularisation - seems to be in evidence among many of Britain's Muslims, Sikhs, and Hindus.

Thirdly, as we witnessed above, the social spaces of religiosity are changing. This invites us to think beyond the over-used categories of >membership and sattendance $<$ as indicators of participation in religious and spiritual life, to such things as inter-faith encounter, new civic-religious partnerships, and shared cross-cultural experience as alternative ways of understanding the socio-spatial nature of religiosity in cosmopolitan Britain.

Fourthly, with the emergence of a new discursive space of religion in government policy, the law and the workplace, it becomes pertinent to ask whether religion has successfully re-entered the public domain from which it was so recently declared absent by secularisation theorists. In Britain, at least, the physical and political presence of Muslims, Sikhs and Hindus seems to have slowed and challenged the process of secularisation, forcing government and other public institutions to once again recognise religious claims.

Although these four conclusions about the changing nature of the religious landscape apply at the national scale, it is our spatial examination of local cases which makes them convincing. As anthropologist, Thomas Hylland Eriksen (1995) wrote, »small places, large issues«. For each small place contains within it examples of processes at work at national and global levels (Martikainen 2004). I have suggested here that a spatial analysis can reveal the layers of history and meaning, the power struggles, and the spatial expression and representation by religious groups of their motivations and aspirations in everyday local context. And, working inductively, this can raise vital questions for us to investigate in relation to other local cases, and to pursue more generally and comparatively at national and international levels.

\section{References}

Alam, Fareena (2004): »Take the honour out of killing«, in: The Guardian 06.07 .2004 .

Allison, Rebecca (2003): »Where's the honour in this?«, in: The Guardian 03.10.2003.

Asthana, Anushka/Mistry, Ushma (2003): »For families that fear dishonour, there is only one remedy... murder «, in: The Observer 05.10.2003. 
Ash, Amin (2002): »Ethnicity and the multicultural city: living with diversity«, in: Environment and Planning A 34, 6, pp. 959-980.

Badham, Paul (ed.) (1989): Religion, State and Society in Britain, Lewiston/Queenston/Lampeter: Edwin Mellen Press.

Baumann, Gerd (I996): Contesting Culture: Discourses of Identity in Multi-Ethnic London, Cambridge: Cambridge University Press.

Binfield, Clive (I994): »The history of Button Hill: an essay in Leeds non-conformity«, in: Alistair Mason (ed.), Religion in Leeds, Stroud: Alan Sutton, pp. 79-107.

Blair, Tony (200I): »Faith in politics«, speech by Tony Blair to the Christian Socialist Movement, London, 29.03.200I, www.experien cecorps.co.uk/docs/fd.asp?doc=faith_mar_oI_I.pdf, accessed 27 . II.2004.

Brierley, Peter (1998): UK Christian Handbook: Religious Trends, 1998-9, Christian Research with Paternoster Publishing.

Burlet, Stacey/Reid, Helen (1998): Faith in the Future: People of Faith, Social Action and the City of Leeds, Leeds: Department of Theology and Religious Studies, University of Leeds with Leeds Church Institute.

Caglar, Ayse (I997): »Hyphenated identities and the limits of culture«, in: Tariq Modood/Pnina Werbner (ed.), The Politics of Multiculturalism in the New Europe, London: Zed Books, pp. I69-185.

Cady, Linell E. (I998): »The public intellectual and effective critique«, in: The Council of Societies for the Study of Religion Bulletin 27, 2, pp. 36-38.

Census 200I, www.statistics.gov.uk/census2001/, accessed 27.II.2004.

de Certeau, Michel (I984): The Practice of Everyday Life, Berkeley: University of California Press.

Chidester, David/Linenthal, Edward T. (ed.) (I995): American Sacred Space, Bloomington and Indianapolis: Indiana University Press.

Chivallon, Christine (200I): »Religion as space for the expression of Caribbean identity in the United Kingdom«, in: Environment and Planning D: Society and Space I9, pp. 46I-483.

Davie, Grace (1994): Religion in Britain since 1945: Believing Without Belonging, Oxford and Cambridge MA: Blackwell.

Dodd, Vikram (2003): »Kurd who slit daughter's throat in >honour killing < is jailed for life«, in: The Guardian 30.09.2003.

Dwyer, Claire (I993): »Constructions of Muslim identity and the contesting of power: the debate over Muslim schools in the $\mathrm{UK}_{\ll}$, in: Peter Jackson/J. Penrose (ed.), Constructions of Race, Place and Nation, London: UCL Press. 
Dwyer, Claire (I999a): »Contradictions of community: questions of identity for young British Muslim women«, in: Environment and Planning A 3I, pp. 53-68.

Dwyer, Claire (1999b): »Veiled Meanings: young British Muslim women and the negotiation of differences«, in: Gender, Place and Culture 6, pp. 5-26.

Eade, John (1996): »Nationalism, community and the Islamization of space in London«, in: Barbara Daly Metcalf (ed.), Making Muslim Space in North America and Europe, Berkeley: University of California Press, pp. 217-233.

Eade, John (2000): Placing London: From Imperial Capital to Global City, New York and Oxford: Berghahn Books.

Eriksen, Thomas Hylland (1995): Small Places, Large Issues: An Introduction to Social and Cultural Anthropology, London: Pluto.

Faith Communities Unit, Home Office, http://www.homeoffice.gov.uk/ docs3/workingtog_faitho40329.pdf, accessed 29.II.2004.

Gay, John (197I): The Geography of Religion in England, London: Duckworth.

Gale, Richard/Naylor, Simon (2002): »Religion, planning and the city: the spatial politics of ethnic minority expression in British cities and towns«, in: Ethnicities 2, pp. 387-409.

Gupta, Rahila (2003) »A veil drawn over brutal crimes«, in: The Guardian 02.10.2003.

Hathisoft (Sikhism in Leeds), http://www.hathisoft.com/sikhism/Gurd waras/gurdindx.htm, accessed 27.II.2004.

Isaac, Erich (1965): »Religious geography and the geography of religions «, in: Man and the Earth, University of Colorado Studies, Series in Earth Sciences 3, pp. I-I4.

Inter Faith Network for the UK, www.interfaith.org.uk, accessed 27.II. 2004.

Jackson, Peter (2000): »Rematerializing social and cultural geography«, in: Social and Cultural Geography I, pp. 9-I4.

Kalsi, Sewa Singh (1992): The Evolution of a Sikh Community in Britain, Leeds: Community Religions Project, University of Leeds.

Kong, Lily (200I): »Mapping >new< geographies of religion: politics and poetics in modernity«, in: Progress in Human Geography 25, pp. 2II-233.

Knott, Kim (I984): »Community religions at the University of Leeds«, in: Community Religions Project Research Papers I, Leeds: Department of Theology and Religious Studies, University of Leeds.

Knott, Kim (I988): »The Community Religions Project Past and Present«, in: Journal of Beliefs and Values 9, 2, pp. 8-II. 
Knott, Kim (I997): »The religions of South Asian communities in Britain«, in: John Hinnells (ed.), A New Handbook of Living Religions, Oxford: Blackwell, pp. 756-774.

Knott, Kim (1998): »Issues in the study of religions and locality«, in: Method and Theory in the Study of Religions 10, pp. 279-290.

Knott, Kim (2000a): »Hinduism in Britain«, in: Harold Coward/John R. Hinnells/Raymond Brady Williams (ed.), The South Asian Religious Diaspora in Britain, Canada and the United States, Albany NY: State University of Albany Press, pp. 89-107.

Knott, Kim (2000b): »Community and locality in the study of religions «, in: Tim Jensen/Mikael Rothstein (ed.), Secular Theories in the Study of Religions, Copenhagen: Museum Tusculanum Press, pp. 87 -105.

Knott, Kim (2004a): »Britain's changing religious landscape: drowning or waving? «, in: Bericht zur deutschen Landeskunde 78, 2, pp. 213229 .

Knott, Kim (2004b): »The sense and nonsense of >community«", in: Steven J. Sutcliffe (ed.), Religion: Empirical Studies, Aldershot and Burlington: Ashgate, pp. 67-90.

Knott, Kim (2005): The Location of Religion: A Spatial Analysis of the Left Hand, London: Equinox.

Knott, Kim/Kalsi, Sewa Singh (I994): »The advent of Asian religions«, in: Alistair Mason (ed.), Religion in Leeds, Stroud: Alan Sutton, pp. I6I-I79.

Knott, Kim/McLoughlin, Séan/Prideaux, Melanie (2003): The Feasibility of a Faith Forum for Yorkshire and the Humber: Final Report, Leeds: Community Religions Project in association with the Yorkshire and Humber Assembly and Churches Regional Commission.

Knott, Kim/Randolph-Horn, David (2002): Religious Literacy: A Guide to the Region's Faith Communities, Wakefield: Yorkshire and Humber Assembly.

Knott, Kim/Ward, Kevin/Mason, Alistair/Willmer, Haddon (ed.) (in press): Religion and Locality, Leeds: Community Religions Project, University of Leeds.

Knott Kim/Toon Richard (1982): »Muslims, Sikhs and Hindus in the UK: problems in the estimation of religious statistics«, in: Religious Research Papers 6, Leeds: Department of Sociology, University of Leeds.

Kumar, Krishan (2003): The Making of English National Identity, Cambridge: Cambridge University Press.

Lefebvre, Henri (I99I [1974]): The Production of Space, Oxford and Cambridge MA: Blackwell. 
Local Government Association, www.lga.gov.uk, accessed 27.II.2004. Martikainen, Tuomas (2004): Immigrant Religions in Local Society: Historical and Contemporary Perspectives in the City of Turku, Åbo: Åbo Akademi University Press.

Mason, Alistair (ed.) (1994): Religion in Leeds, Stroud: Alan Sutton.

McCutcheon, Russell T. (1997): »A default of critical intelligence? The scholar of religion as public intellectual«, in: Journal of the American Academy of Religion 65, 2, pp. 443-468.

McLoughlin, Séan (1998): »An Underclass in Purdah: discrepant representations of identity and the experiences of Young-British-AsianMuslim-Women «, in: Bulletin of the John Rylands University Library of Manchester, 80, 3, pp. 89-106.

McLoughlin, Séan (2005): »Mosques and the Public Space: Conflict and Cooperation in Bradford«, in: Journal of Ethnic and Migration Studies 31, 6.

Metcalf, Barbara Daly (ed.) (1996): Making Muslim Space in North America and Europe, Berkeley: University of California Press.

Muir, Richard (1999): Approaches to Landscape, Basingstoke and London: Macmillan.

Naylor, Simon/Ryan, James (2002): »The mosque in the suburbs: negotiating religion and ethnicity in South London«, in: Social and Cultural Geography 3, pp. 39-59.

Naylor, Simon/Ryan, James (in press): »Tracing the geographies of religious minorities in the UK: using surveys and case studies«, in: Kim Knott/Haddon Willmer/Kevin Ward/Alistair Mason (ed.) Religion and Locality, Leeds: Community Religions Project, University of Leeds.

Neighbourhood Renewal Unit (Office of the Deputy Prime Minister), http://www.neighbourhood.gov.uk/faith_communities.asp, accessed 27. II.2004.

Nesbitt, Eleanor (1998): »British, Asian and Hindu: identity, self-narration and the ethnographic interview «, in: Journal of Beliefs and Values i9, pp. I89-200.

Nye, Malory (200I): Multiculturalism and Minority Religions in Britain, Richmond: Curzon.

Parekh, Bhikhu (2000a): Rethinking Multiculturalism: Cultural Diversity and Political Theory, Basingstoke: Macmillan.

Parekh, Bhikhu (2000b): »Defining British national identity«, in: Political Quarterly 7I, pp. 4-I4.

Park, Chris (I994): Sacred Worlds: An Introduction to Geography and Religion, London: Routledge. 
Parsons, Gerald (ed.) (I993): The Growth of Religious Diversity: Britain from 1945, Vol I: Traditions, London: Routledge/Open University Press.

Peach, Ceri (2002): »Social geography: new religions and ethnoburbs contrasts with cultural geography«, in: Progress in Human Geography 26, pp. 252-26o.

Phillips, Deborah (n.d.): »Asian mobility in Leeds and Bradford «, Leeds: School of Geography, University of Leeds, www.geog.leeds.ac. uk/projects/mobility/, accessed 27.II.2004.

Poole, Elizabeth (2002): Reporting Islam: Media Representations of British Muslims, London: I. B. Tauris.

Prideaux, Melanie (2004): »Faiths together? The effects and implications for Muslims and Christians of joint community projects publicly funded «, paper given at the $50^{\text {th }}$ Anniversary Conference of the British Association for the Study of Religions, Oxford, I6.09.2004.

Pye, Michael (I977): »A paper presented at the Senior Seminar, I6 March I977«, in: Community Religions Project Working Paper 3, Leeds: Department of Theology and Religious Studies, University of Leeds.

Ridout, J. (2000): »Religion and >the heritage < in Britain«, in: Crispin Paine (ed.), Godly Things: Museums, Objects and Religion, London and New York: Leicester University Press, pp. 210-227.

Thomas, Terence (ed.) (I988): The British: Their Religious Beliefs and Practices 1800-1986, London: Routledge.

Tobler, Judy (2000): »>Home is where the heart is?<: Gendered sacred space in South Africa«, in: Journal for the Study of Religion 13, pp. 69-98.

Toon, Richard (I977): »A study of the Sikhs in Leeds«, in: Community Religions Project Research Paper 3, Leeds: Department of Theology and Religious Studies, University of Leeds.

Valins, Oliver (2003): »Stubborn identities and the construction of socio-spatial boundaries: ultra-orthodox Jews living in contemporary Britain«, in: Transactions of the Institute of British Geographers NS 28, pp. I58-I75.

Vertovec, Steven (2004): »Religion and diaspora«, in: Peter Antes/ Armin W. Geertz/Randi Warne (ed.), New Approaches to the Study of Religion, Berlin and New York: Verlag de Gruyter, pp. 275-304.

Vertovec, Steven/Cohen, Robin (ed.) (I999): Migration, Diasporas and Transnationalism, Aldershot: Ashgate.

Weller, Paul (ed.) (200I): Religions in the UK: Directory 2001-03, Derby: Multi-Faith Centre at the University of Derby in association with the Inter Faith Network for the UK, third edition. 
Weller, Paul/Feldman, Alice/Purdam, Keith (200I): Religious Discrimination in England and Wales: Home Office Research Study 220, London: The Home Office.

Werbner, Pnina (1996): »Stamping the earth with the name of Allah: Zikr and the sacralizing of space among British Muslims«, in: Barbara Daly Metcalf (ed.), Making Muslim Space in North America and Europe, Berkeley: University of California Press, pp. I67-185.

Yorkshire and Humber Regional Assembly, www.rayh.gov.uk, accessed 27.II.2004. 